\title{
Androgen Receptor Content of the Normal and Hyperplastic Canine Prostate
}

\author{
Sydney A. Shain and Robert W. Boesel, Tom Slick Memorial Laboratories, \\ Southwest Foundation for Research and Education, San Antonio, Texas 78284
}

\begin{abstract}
A B S T RACT A procedure was developed for measurement of androgen receptors in cytoplasmic extracts of prostates from intact dogs. The protocol utilized exchange saturation analysis at $15^{\circ} \mathrm{C}$ employing the synthetic androgen R1881 (17 $\beta$-hydroxy-17 $\alpha$-methylestra-4,9,11-trien-3-one) as the ligand probe and quantitatively detected total cytoplasmic androgen receptor $\left(R_{c}\right.$, androgen-free receptor, and $R_{c} A$, androgenoccupied receptor) present at the initiation of the assay. This protocol was employed in conjunction with a tissue mince saturation analysis procedure (for quantitation of nuclear androgen receptor) to quantitate total androgen receptor content of normal and hyperplastic prostates obtained from young (2.5- or 4.6-yr old) and aged (12.5-yr old) purebred dogs of known birth date.

The total cytoplasmic androgen receptor content (picomoles per prostate) of hyperplastic prostates was 4.6 -fold greater than that of normal prostates. The total nuclear androgen receptor content of hyperplastic prostates (picomoles per prostate measured in crude nuclear preparations) was either 5.0- (4.6-yr-old dogs) or 7.8-fold (2.5-yr-old dogs) greater than that of normal prostates. However, androgen receptor content per cell was identical for hyperplastic and normal canine prostates, with the exception that nuclear androgen receptor was diminished in prostates from 2.5-yr-old dogs. The cell content per gram dry weight was identical for hyperplastic and normal canine prostates. We conclude that canine prostate hyperplasia is characterized by coordinate proliferation of androgen receptor-positive and androgen receptor-negative cells and is not a consequence of increased accumulation of $5 \alpha$-dihydrotestosterone due to proliferation of androgen receptors per prostate cell.
\end{abstract}

\section{INTRODUCTION}

The common occurrence of prostatic hyperplasia in man and the $\operatorname{dog}(1-3)$, and advances in elucidation of

Received for publication 3 June 1977 and in revised form 21 October 1.977 . the molecular mechanisms of hormone action have led to an increasing number of investigations of hormonal regulation of canine prostate function (4-10). Although histologic features (11) and hormone sensitivity $(3,4$, 12-14) of the two prostatic hyperplasias differ, the induction of canine prostatic hyperplasia by injection of androstanediol $^{1}$ or androstanediol plus $17 \beta$-estradiol (9) supports the use of the canine model for studies of pathogenesis. When compared to normal prostates, both human and canine prostatic hyperplasia are characterized by an approximately fivefold increase (7, $15)$ in the concentration of the prostatic androgen $5 \alpha$-dihydrotestosterone (16). However, the rate of conversion of testosterone to $5 \alpha$-dihydrotestosterone is not significantly different for normal and hyperplastic prostates of either specie $(7,15)$. The observations suggest that an alteration in the mechanism of $5 \alpha$ dihydrotestosterone accumulation may be related to the pathogenesis of prostatic hyperplasia.

Current concepts of the mechanism of steroid hormone regulation of cell function envisions a process whereby effector steroid initially interacts with cytoplasmic receptor proteins. The highly steroid specific binding of effector to cytoplasmic receptor protein promotes translocation of the receptor-steroid complex into the nuclear compartment $(17,18)$. Consequently, the capacity of the prostate to specifically accumulate $5 \alpha$-dihydrotestosterone (effector steroid) would be expected to be related to the tissue content of cytoplasmic and nuclear androgen receptor. As part of a study of aging-associated changes in steroid hormone

\footnotetext{
${ }^{1}$ Abbreviations and trivial names used in this paper: androstanediol, $5 \alpha$-androstane- $3 \alpha, 17 \beta$-diol, $3 \alpha, 17 \beta$-dihydroxyandrostane; $\Delta^{4}$-androstenedione, 4-androstene-3,17dione; cortisol, $11 \beta, 17 \alpha, 21$-trihydroxy-4-pregnene-3,20-dione; $5 \alpha$-dihydrotestosterone, $\quad 17 \beta$-hydroxy- $5 \alpha$-androstan-3-one; $17 \beta$-estradiol, 1,3,5(10)-estratriene-3,17 $\beta$-diol; $7 \alpha$-methyl- $\Delta^{14}$ 19-nortestosterone, $7 \alpha$-methyl-17 $\beta$-hydroxy-4,14-estradien-3one; 19-nortestosterone, 17 $\beta$-hydroxy-4-estren-3-one; progesterone, 4-pregnene-3,20-dione; R1881, 17 $\beta$-hydroxy-17 $\alpha$ methyl-estra-4,9,11-trien-3-one; $R_{c}$, androgen-free receptor; $R_{c} A$, androgen-occupied receptor.
} 
regulation of target tissue function, we have characterized and quantitated androgen receptor content of normal and hyperplastic prostates of aging dogs. The results of these studies are the subject of this communication.

\section{METHODS}

Animals. Mongrel dogs of indeterminate age were used for protocol development. Definitive experiments employed purebred dogs of known birth date. The 2.5- and 4.6-yr-old subject groups both consisted of three beagles obtained from Theracon, Inc., Topeka, Kans., and Marshal Research Animals, North Rose, N. Y., respectively. The 12.5-yr-old subject group consisted of two beagles, one obtained from Hazleton Research Animals, Cumberland, Va., and the other from $\mathbf{H}$. Barb Beagles, Inc., Essexville, Mich.; and one bloodhound obtained from the Texas Department of Corrections, Huntsville, Tex. None of the purebred dogs had been subjected to experimentation before receipt at Southwest Foundation, where they were maintained in kennels for a period of $3 \mathrm{wk}$ to $3.5 \mathrm{yr}$ before sacrifice. Mongrel dogs were orchiectomized as previously described (10) and all dogs were sacrificed by cardiac exsanguination while under Nembutal anesthesia. The AXC rats employed for protocol development were bred in the colony at Southwest Foundation. Their care and maintenance and method of orchiectomy have previously been described (19).

Chemicals. $\quad 5 \alpha-\left[1,2-{ }^{3} \mathrm{H}_{2}\right]$ Dihydrotestosterone, sp act $55 \mathrm{Ci} /$ mmol, was obtained from Amersham/Searle Corp. (Arlington Heights, Ill.) and purified by paper chromatography shortly before use (19). $\left[6,7-{ }^{3} \mathrm{H}_{2}\right] 17 \beta$-Hydroxy-17 $\alpha$-methyl-estra- 4,9 , 11-trien-3-one (R1881), sp act $58.2 \mathrm{Ci} / \mathrm{mmol}$, and radioinert R1881 were generously provided by Dr. Jean-Pierre Raynaud, Centre de Recherches, Roussel-Uclaf, France. Purity of these compounds was monitored by thin-layer chromatography on silica gel employing benzene:ethyl acetate $(1: 1)$ as solvent. $7 \alpha$ Methyl- $\Delta^{14}-19$-nortestosterone was generously provided by Dr. Albert Segaloff, Alton Ochsner Foundation, New Orleans, La. All other radioinert steroids were obtained from Steraloids, Inc., Wilton, $\mathrm{N}$. H. and purity was determined as previously described (19). The preparation and storage of aqueous solutions of radioactive and radioinert steroids have previously been described (19). All other materials were the best reagent quality grade available from the manufacturer. Aqueous solutions were prepared in water which was distilled, deionized, and redistilled from glass.

Quantitation of available cytoplasmic androgen receptor sites $\left(\mathrm{R}_{\mathrm{c}}\right)$ in tissue from orchiectomized or intact subjects was achieved by saturation analysis as previously described $(19,20)$ with the exception that radiolabeled R1881 was employed as the ligand probe. Prostates from intact dogs were processed for the preparation of cytoplasmic extracts (cytosol) as previously described (10). Endogenous steroids were removed from rat ventral prostate or canine prostate cytosol by mixing with a charcoal pellet obtained by centrifugation, $1,000 \mathrm{~g}$ for $5 \mathrm{~min}$ at $2^{\circ} \mathrm{C}$, of 0.1 volume of $5 \%$ Norit, $0.5 \%$ dextran T70, $1 \%$ human $\gamma$-globulin in $50 \mathrm{mM}$ Tris$\mathrm{Cl}, 0.5 \mathrm{mM} \beta$-mercaptoethanol, $0.1 \mathrm{mM}$ EDTA, $\mathrm{pH} 7.4$. After a 10 -min incubation at $2^{\circ} \mathrm{C}$, charcoal was removed by centrifugation at $10,000 \mathrm{~g}(2 \times 5 \mathrm{~min})$ at $2^{\circ} \mathrm{C}$, and the cytosol preparation was employed for determination of available (unoccupied, $\mathrm{R}_{\mathrm{c}}$ ) and total (occupied, $\mathrm{R}_{\mathrm{c}} \mathrm{A}$, plus unoccupied, $R_{c}$ ) receptor sites. Saturation analysis (total sites) was accomplished by incubating triplicate 100- $\mu$ l aliquots of cytosol with $10 \mathrm{nM}$ radiolabeled R1881 and sufficient radioinert $\mathrm{R} 1881$ to achieve the following final nanomolar concentrations of ligand: $10,15,20,30,40,50,80$, and 110 . After a 24 -h incubation at $15^{\circ} \mathrm{C}$, bound radiosteroid was determined as previously described (10). Nonspecific binding of R1881 was evaluated by incubating cytosol with $10 \mathrm{nM}$ radiolabeled $\mathrm{R} 1881$ plus $1 \mu \mathrm{M}$ radioinert $\mathrm{R} 1881$ and the bound/ free ratio thus determined was employed to calculate nonspecific binding of R1881 in all incubated samples (21).

Validation of the cytoplasmic exchange protocol was achieved employing cytosol prepared from orchiectomized $\operatorname{dogs}(10)$ or rats $(20)$. The cytosol was divided into two portions and one was subjected to saturation analysis (employing the ligand concentrations described above) for determination of $R_{c}$ by incubation with radiolabeled $\mathrm{R} 1881$ at $2^{\circ} \mathrm{C}$ for $2 \mathrm{~h}$. The second portion was incubated with $10 \mathrm{nN} M$ radioinert $\mathrm{R} 188 \mathrm{I}$ for $1.5 \mathrm{~h}$ at $2^{\circ} \mathrm{C}$, treated with $5 \%$ Norit, $0.5 \%$ dextran $\mathrm{T} 70,1 \%$ human $\gamma$-globulin in $50 \mathrm{mM}$ Tris-Cl, $0.5 \mathrm{mM} \beta$-mercaptoethanol, $0.1 \mathrm{mM}$ EDTA, pH 7.4, and then subjected to saturation analysis for determination of $R_{c} A$ plus $R_{c}$ by incubation with radiolabeled $\mathrm{R} 1881$ for $24 \mathrm{~h}$ at $15^{\circ} \mathrm{C}$. Steroid specificity of the cytoplasmic androgen receptor was determined at $2^{\circ}$ or $15^{\circ} \mathrm{C}$ by incubating the appropriate cytosol preparation with $10 \mathrm{nM}$ radiolabeled $\mathrm{R} 1881$ and either $100 \mathrm{nM}\left(2^{\circ} \mathrm{C}\right.$ determinations) or $500 \mathrm{nM}\left(15^{\circ} \mathrm{C}\right.$ determinations) competitor.

Saturation analysis for determination of nuclear androgen receptor content was performed as previously described (10). Duplicate specimens $(200-500 \mathrm{mg})$ of each prostate were dried at $60^{\circ} \mathrm{C}$ in vacuo until a constant weight was achieved. Total tissue content of DNA and RNA was determined upon duplicate specimens as previously described (19). Protein content was determined for the cy toplasmic extracts only (19). Specimens for histopathologic examination were processed as previously described (22). Radioactivity in all samples was counted to $2 \%$ precision as previously described (20).

\section{RESULTS}

The assay procedure was based upon the report of Bonne and Raynaud (23) demonstrating exchange of $\mathrm{R} 1881$ with endogenous ligand during incubation of rat ventral prostate cytosol at $15^{\circ} \mathrm{C}$. Preliminary experiments employing cytosol prepared from canine prostate, obtained $72 \mathrm{~h}$ after orchiectomy, incubated with 10 $\mathrm{nM}$ radiolabeled $\mathrm{R} 1881$ demonstrated the absence of any exchange of radiolabeled ligand with radioinert ligand during a 24-h incubation of $\mathrm{R}_{\mathrm{c}} \mathrm{A}$ at $2^{\circ} \mathrm{C}$. $\mathrm{By}$ contrast, incubation of $\mathrm{R}_{\mathrm{c}} \mathrm{A}$ for $24 \mathrm{~h}$ at $15^{\circ} \mathrm{C}$ caused complete exchange of radiolabeled $\mathrm{R} 1881$ and radioinert R1881 with recovery of the major fraction of $R_{c} A$ originally present. Additional preliminary experiments demonstrated the use of higher concentrations of $\mathrm{R} 1881$ to label $\mathrm{R}_{\mathrm{c}}$ at $2^{\circ} \mathrm{C}$ yielded increased recovery of $R_{c} A$ subsequent to incubation at $15^{\circ} \mathrm{C}$. Thin-layer chromatography of the extracted radiolabeled steroid ( $>95 \%$ recovery of input radioactivity) demonstrated that at least $90 \%$ of the extracted radioactive material was isopolar with authentic R1881. The data indicated that an exchange protocol for quantitation of $R_{c} A$ and $R_{c}$ could be developed by employing saturation analysis at $15^{\circ} \mathrm{C}$. Moreover, quantitation of binding sites by incubation at $15^{\circ} \mathrm{C}$ with a single ligand concentration frequently yielded inaccurate estimates of total binding sites. 
The results of a typical exchange saturation analysis for determination of cytoplasmic androgen-binding site content in the prostate from an intact dog are presented in Fig. $1 \mathrm{~A}$ as a double reciprocal plot. A linear plot of comparable quality was usually obtained when the data were analyzed by the method of Scatchard (24). However, the double reciprocal plot provided a better display of our data for the determination of a binding site concentration and ligand dissociation constant.

The ability of the exchange assay to quantitate androgen-binding sites in prostate cytoplasmic extracts was determined for preparations from three individual orchiectomized rats and four individual orchiectomized mongrel dogs. The available $\left(\mathrm{R}_{\mathrm{c}}\right)$ or prelabeled and exchanged $\left(R_{c} A\right.$ plus $\left.R_{c}\right)$ cytoplasmic androgen-binding sites in rat ventral prostate were $126 \pm 28$ and $145 \pm 26$ (mean \pm SEM) fmol per $\mathrm{mg}$ cytosol protein, respectively. The values for the canine prostate preparations were $44.6 \pm 3.6\left(R_{c}\right)$ and $47.3 \pm 5.3\left(R_{c} A\right.$ plus $\left.R_{c}\right)$ fmol per $\mathrm{mg}$ cytosol protein. The differences in the mean values were not significantly different for either the rodent or

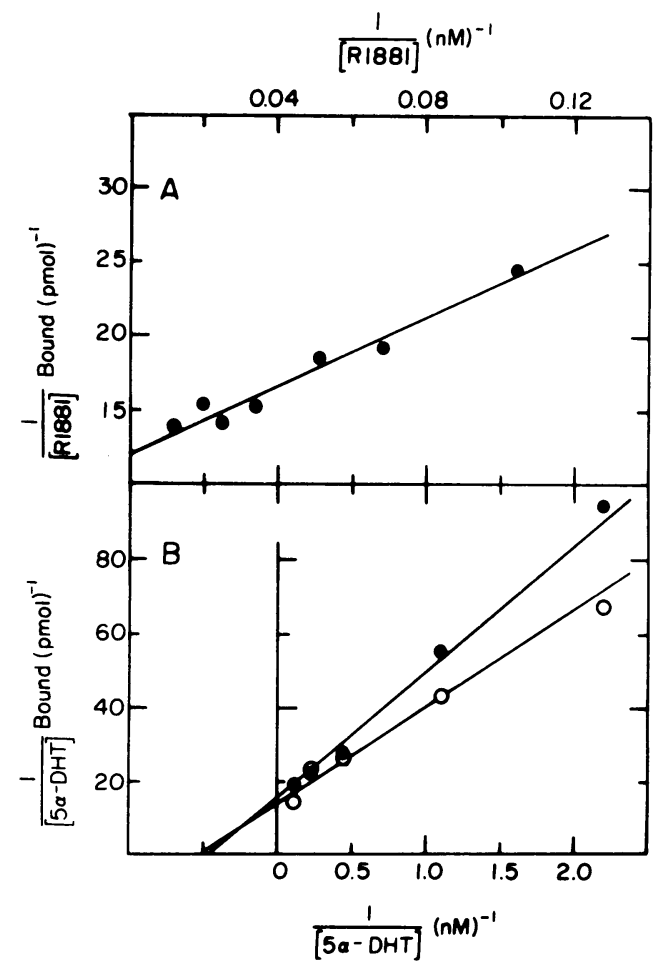

Figure 1 Typical quantitation of canine prostate androgenbinding components in tissue from an intact 2.5-yr-old beagle. (A) Exchange saturation analysis at $15^{\circ} \mathrm{C}$ for quantitation of total cytoplasmic androgen receptors. R1881 binding is picomoles per milligram cytosol protein. (B) Mince saturation analysis at $37^{\circ} \mathrm{C}$, for quantitation of the $\mathrm{KCl}$-extractable $(\mathrm{O})$ and ethanol-extractable (-) fractions of the nuclear androgen receptors. $5 \alpha$-Dihydrotestosterone $(5 \alpha$-DHT) binding is picomoles per 100 microgram DNA.
TABLE I

Steroid Specificity of the Canine and Rat Ventral Prostate Cytoplasmic Androgen Receptor as Measured at $15^{\circ *}$ or $2{ }^{\circ} \mathrm{C}+$

\begin{tabular}{|c|c|c|c|}
\hline \multirow[b]{3}{*}{ Competitors } & \multicolumn{3}{|c|}{$\begin{array}{l}\text { Specific binding, }\} \\
\% \text { control }\end{array}$} \\
\hline & \multicolumn{2}{|c|}{$\begin{array}{l}\text { Canine } \\
\text { prostate }\end{array}$} & \multirow{2}{*}{$\begin{array}{c}\begin{array}{c}\text { Rat } \\
\text { prostate }\end{array} \\
15^{\circ} \mathrm{C}\end{array}$} \\
\hline & $2^{\circ} \mathrm{C}$ & $15^{\circ} \mathrm{C}$ & \\
\hline None & 100 & 100 & 100 \\
\hline $\mathrm{R} 1881$ & 5 & 2 & 3 \\
\hline $5 \alpha$-Dihydrotestosterone & 29 & 29 & 2 \\
\hline 19-Nortestosterone & 24 & 19 & 2 \\
\hline $7 \alpha$-Methyl- $\Delta^{14}$-19-nortestosterone & $N P^{\|}$ & 30 & 4 \\
\hline $5 \alpha$-Androstane- $3 \alpha, 17 \beta$-diol & 86 & 74 & 47 \\
\hline$\Delta^{4}$-Androstenedione & 97 & 100 & 86 \\
\hline $17 \beta$-Estradiol & 57 & 91 & 79 \\
\hline Progesterone & 55 & 74 & 86 \\
\hline Cortisol & 100 & 96 & 90 \\
\hline
\end{tabular}

* Cytoplasmic extracts were prepared from prostates obtained from intact animals and incubated with $10 \mathrm{nM}$ radiolabeled $\mathrm{R} 1881$ or $10 \mathrm{nM}$ radiolabeled $\mathrm{R} 1881$ plus $500 \mathrm{nM}$ competitor for $24 \mathrm{~h}$ at $15^{\circ} \mathrm{C}$. Data are the mean of two or three independent determinations.

\$ From reference 10 .

$\$$ Specific binding was calculated as the amount of receptor bound radiolabeled $\mathrm{R} 1881$ after incubation in the presence or absence of competitor. All data were corrected for nonspecific binding as determined by incubation of cytosol with $10 \mathrm{nM}$ radiolabeled $\mathrm{R} 1881$ in the presence of $1 \mu \mathrm{M}$ radioinert R1881.

"NP, determination not performed.

canine determinations, and demonstrated the exchange saturation protocol quantitatively detected prostate cytoplasmic androgen-binding components present at the initiation of the protocol.

Steroid specificity of the cytoplasmic androgenbinding sites, as measured at $15^{\circ} \mathrm{C}$ (Table I), demonstrates that only potent androgens effectively inhibit specific binding of R1881 by rodent or canine prostate cytosol. Steroid specificity in canine prostate cytosol is comparable for incubations performed at either $2^{\circ}$ or $15^{\circ} \mathrm{C}$ with the exception that $17 \beta$-estradiol and progesterone are less effective inhibitors at $15^{\circ}$ than at $2^{\circ} \mathrm{C}$. The data (Table I) demonstrate potent androgens to be relatively more effective inhibitors of $\mathrm{R} 1881$ binding in rat prostate cytosol than in canine prostate cytosol.

The results of a typical saturation analysis for quantitation of nuclear androgen receptors in prostates from intact purebred dogs are presented in Fig. $1 \mathrm{~B}$ and are comparable to our results previously reported for prostate from mongrel dogs (10).

The prostates of the purebred dogs were separated into two groups, mature (4-14 g) and hyperplastic 
glands (>14 g) according to the criteria of Berg (3). Light microscopic examination showed that prostates from 2.5- and 4.6-yr-old dogs were principally composed of compact alveoli lined by intensely eosinophilic, granular, cuboidal-to-columnar epithelium. Intraluminal papillary projections of the epithelium were observed in some glands. Modest dilation of scattered alveoli or clusters of alveoli was observed. Thus, the histologic features of these specimens were those of normal mature canine prostates. Prostates from 12.5-yr-old dogs were principally composed of markedly dilated alveoli containing numerous papillary projections of epithelium. The epithelial cells were columnar and contained uniform, basally located, hyperchromatic nuclei. The lumens of some smaller alveoli were completely filled by papillary projections of epithelium and supporting stroma. The histologic features of these specimens were characteristic of canine prostate hyperplasia.

The composition of prostates from 2.5- and 4.6-yr-old dogs, as measured by DNA, RNA, and protein content or percent dry weight, was indistinguishable (Table II). Moreover, the mean number of cells per prostate and the RNA and protein content per cell was not significantly different for these two groups of dogs. Hyperplastic prostates from 12.5-yr-old dogs were distinguished from those of other subjects by a sevenfold increase in mass which was principally attributable to a greater than fivefold proliferation of cells as measured by DNA, RNA, and protein content
(Table II). In addition, there was a reproducible but not statistically significant $(0.1>P>0.05)$ increase in the fluid content of hyperplastic prostates when compared to normal prostates. Significantly, the composition of hyperplastic prostates was indistinguishable from normal prostates when expressed as milligrams DNA, RNA, or protein per gram dry weight (Table II).

Available $\left(R_{c}\right)$ and total $\left(R_{c} A\right.$ plus $\left.R_{c}\right)$ cytoplasmic androgen-binding site content of the prostates from 2.5and 4.6-yr-old dogs was not significantly different when measured either as picomoles per prostate or as sites per cell (Table III). Nuclear androgen receptor sites per cell or content per prostate was significantly greater in prostates from 4.6- as compared to 2.5 -yr-old dogs. The mean available or total cytoplasmic androgen-binding site content (picomoles per prostate) of hyperplastic canine prostates, respectively, was 5.2 - or 4.6 -fold greater than that of normal canine prostates. The mean nuclear androgen receptor content (picomoles per prostate) of hyperplastic canine prostates respectively was 5.0- and 7.8-fold greater than that of 4.6- and 2.5-yr-old dogs (Table III). Significantly, androgenbinding site content per cell is identical for hyperplastic and normal canine prostates, with the exception that nuclear binding sites per cell in prostates from 2.5-yr-old dogs are significantly decreased (Table III).

The steroid dissociation constants of the cytoplasmic androgen-binding sites or the ethanol-extractable portion of the nuclear androgen receptors of hyperplastic and normal canine prostates are not significantly

TABLE II

Composition of the Prostate of the Aging Canine*

\begin{tabular}{|c|c|c|c|c|c|c|c|c|c|}
\hline \multirow[b]{3}{*}{ Age } & \multirow{2}{*}{\multicolumn{3}{|c|}{ Prostate wt $t$}} & \multicolumn{6}{|c|}{ Component content $\S$} \\
\hline & & & & \multicolumn{3}{|c|}{$\mathrm{mg} /$ Prostate } & \multicolumn{3}{|c|}{$\mathrm{mg} / \mathrm{g}$ Dry wt } \\
\hline & Total & urethra & Dry wt & DNA & RNA & Protein & DNA & RNA & Protein \\
\hline$y r$ & $g$ & $g$ & $\%$ & & & & & & \\
\hline 2.5 & $\begin{array}{c}7.21 \pm 1.69 \\
(4.1-9.7)^{* *}\end{array}$ & $5.40 \pm 1.29$ & $23.0 \pm 0.9$ & $32.7 \pm 7.4 \uparrow$ & $29.9 \pm 8.8$ & $308 \pm 729$ & $26.4 \pm 1.4$ & $23.4 \pm 1.5$ & $247 \pm 0.3$ \\
\hline 4.6 & $\begin{array}{l}7.62 \pm 1.19 \\
(6.3-9.7)\end{array}$ & $5.86 \pm 0.809$ & $22.7 \pm 1.1$ & $29.0 \pm 5.09$ & $28.8 \pm 4.6$ & $338 \pm 42 \pi$ & $21.9 \pm 2.8$ & $21.6 \pm 0.8$ & $255 \pm 8$ \\
\hline 12.5 & $\begin{array}{c}51.3 \pm 8.4 \\
(3.5-61)\end{array}$ & $39.8 \pm 7.3$ & $16.9 \pm 2.1$ & $166 \pm 25$ & $131 \pm 25$ & $1,830 \pm 320$ & $25.8 \pm 3.2$ & $20.1 \pm 2.0$ & $280 \pm 29$ \\
\hline
\end{tabular}

\footnotetext{
* Prostates were obtained from intact dogs. Data are the mean \pm SEM for determinations performed upon tissue from three dogs in each category.

$\$$ Dry weight is expressed as percent of tissue obtained after removal of the urethra.

$\$$ All data are based upon tissue weight after removal of the urethra.

"The DNA and RNA values represent total tissue content, whereas the protein value was only measured for the $100,000 \mathrm{~g}$ supernate of the tissue homogenate.

I Significantly different from the value for 12.5-yr-old dogs as determined by analyses of variance. Absence of symbol indicates absence of a significant difference.

** Weight range.
} 
TABLE III

Androgen Receptor Content of the Prostate of the Aging Canine*

\begin{tabular}{|c|c|c|c|c|c|c|}
\hline \multirow[b]{4}{*}{ Age } & \multicolumn{6}{|c|}{ Receptor sites } \\
\hline & \multicolumn{3}{|c|}{ pmol/prostate } & \multicolumn{3}{|c|}{ Sites/cell } \\
\hline & \multicolumn{2}{|c|}{ Cytoplasmic } & \multirow[b]{2}{*}{ Nuclear } & \multicolumn{2}{|c|}{ Cytoplasmic } & \multirow[b]{2}{*}{ Nuclear } \\
\hline & Available & Total & & Available & Total & \\
\hline \multicolumn{7}{|l|}{$y r$} \\
\hline 2.5 & $4.30 \pm 1.28 \S$ & $26.9 \pm 6.0 \S$ & $47.5 \pm 12.3 \S$ & $440 \pm 69$ & $2,740 \pm 18$ & $4,860 \pm 860 \S$ \\
\hline 4.6 & $4.03 \pm 1.78 \S$ & $23.1 \pm 4.5 \S$ & $74.0 \pm 13 \S$ & $414 \pm 137$ & $2,620 \pm 62$ & $8,490 \pm 570$ \\
\hline 12.5 & $21.7 \pm 4.6$ & $115 \pm 15$ & $372 \pm 65$ & $458 \pm 123$ & $2,350 \pm 230$ & $7,800 \pm 850$ \\
\hline
\end{tabular}

* As defined in Table II.

\$ Cytoplasmic receptor sites were determined by saturation analysis employing radiolabeled R1881. Available sites were determined by incubation at $2^{\circ} \mathrm{C}$ for $2 \mathrm{~h}$ and total sites were determined by incubation at $15^{\circ} \mathrm{C}$ for $24 \mathrm{~h}$. Nuclear sites were quantitated by mince saturation analysis at $37^{\circ} \mathrm{C}$ for $4 \mathrm{~h}$ employing radiolabeled $5 \alpha$-dihydrotestosterone as probe.

$\S$ Significantly different $(P<0.05)$ from the value for 12.5 -yr-old dogs as determined by analyses of variance. Absence of an $\S$ indicates absence of a significant difference.

"Significantly different $(P<0.05)$ from the value for 4.6 -yr-old beagles.

different (Table IV). A statistically significant increase in the dissociation constant of the $\mathrm{KCl}$-extractable portion of the nuclear androgen receptors of prostates from 4.6-yr-old dogs was observed (Table IV).

\section{DISCUSSION}

An assay procedure was developed for the quantitation of total $\left(\mathrm{R}_{\mathrm{c}}\right.$ plus $\left.\mathrm{R}_{\mathrm{c}} \mathrm{A}\right)$ cytoplasmic androgen-binding sites in prostate tissue obtained from either intact dogs or rats. Exchange of endogenous steroid with radiolabeled probe was demonstrated to quantitatively detect total $\left(R_{c}\right.$ plus $\left.R_{c} A\right)$ cytoplasmic androgen-binding

TABLE IV

Apparent Dissociation Constants for Cytoplasmic and Nuclear Androgen Receptors of the Prostate of the Aging Canine*t.

\begin{tabular}{rcclll}
\hline & \multicolumn{2}{c}{ Cytoplasmic $\mathrm{K}_{\mathrm{D}} \times 10^{\circ}(\mathrm{M})$} & & \multicolumn{2}{c}{ Nuclear $\mathrm{K}_{\mathrm{D}} \times 10^{9}(\mathrm{M})$} \\
\cline { 2 - 3 } \cline { 5 - 6 } Age & $2^{\circ} \mathrm{C}$ & $15^{\circ} \mathrm{C}$ & & $\mathrm{KCl}$ & Ethanol \\
\hline$y r$ & & & & & \\
2.5 & $1.08 \pm 0.26$ & $13.1 \pm 3.0$ & & $2.12 \pm 0.12$ & $1.92 \pm 0.22$ \\
4.6 & $0.86 \pm 0.02$ & $20.4 \pm 4.0$ & & $3.51 \pm 0.56 \S$ & $2.62 \pm 0.11$ \\
12.5 & $0.80 \pm 0.01$ & $12.8 \pm 3.0$ & & $1.71 \pm 0.29$ & $1.63 \pm 0.44$ \\
\hline
\end{tabular}

* As defined in Table II.

‡ Ligand probe for cytoplasmic and nuclear saturation analyses, respectively, was radiolabeled $\mathrm{R} 1881$ and radiolabeled $5 \alpha$-dihydrotestosterone. Data are the mean \pm SEM for three independent determinations.

$\$$ Significantly different $(P<0.05)$ from the value for 12.5 -yrold dogs as determined by analyses of variance. Absence of an $\$$ indicates absence of a significant difference. sites present at the initiation of the exchange assay. Steroid specificity of cytoplasmic binding sites measured in the exchange assay was essentially identical to that previously demonstrated for canine prostate cytoplasmic androgen receptors (Table I, reference 10) and was comparable to that of rat ventral prostate cytoplasmic androgen receptor (Table I). Mean apparent steroid dissociation constants of the canine, 15.4 \pm 2.2 $\mathrm{nM}$, or rat ventral prostate, $24.5 \pm 6.2 \mathrm{nM}$, cytoplasmic binding components, measured in the exchange assay, were not significantly different $(0.1>P>0.05)$. The decrease in the apparent steroid dissociation constants of the canine and rat prostate cytoplasmic binding sites, measured in the exchange assay, compared to the steroid dissociation constants of the corresponding cytoplasmic androgen receptors $(10,19)$, measured at $2^{\circ} \mathrm{C}$, may be attributable to effects of elevated temperature which diminish stability of binding sites at low ligand concentration or alter binding kinetics. The properties of the cytoplasmic binding sites measured by the exchange saturation analysis are consistent with identification of these macromolecules as prostatic cytoplasmic androgen receptors.

The total cytoplasmic androgen receptor content of hyperplastic canine prostates was 4.6-fold greater than that of normal prostates, whereas the total nuclear androgen receptor content (measured in crude nuclear preparations) of hyperplastic prostates was either 5.0-(4.6-yr-old subjects) or 7.8-fold (2.5-yr-old subjects) greater than that of normal prostates. That the increased androgen receptor content of the hyperplastic canine prostate may be primarily attributable to proliferation of receptor-containing cells is indicated by the observation (Table III) that receptor sites per cell of the 
hyperplastic prostate are identical to that of the normal canine prostate. The single exception being that nuclear androgen receptor sites are diminished in normal prostates from 2.5-yr-old dogs. Since cell content per gram dry weight of hyperplastic prostates is identical to normal prostates (Table II), the data imply coordinate proliferation of receptor-positive and receptor-negative cells in canine prostatic hyperplasia.

Our data permit calculation of the maximum amount of $5 \alpha$-dihydrotestosterone which may be expected to be specifically bound to canine prostate androgen receptors. Mean values for normal and hyperplastic canine prostates are 0.335 and $0.275 \mu \mathrm{g} / 100 \mathrm{~g}$ wet weight tissue, respectively. The calculated value for normal canine prostates $(0.335 \mu \mathrm{g} / 100 \mathrm{~g})$ is identical to the determination of Gloyna et al. (7) who used a double isotope derivative technique for quantitation of canine prostate $5 \alpha$-dihydrotestosterone content. The data support our conclusion that the saturation analyses are measuring physiologically significant binding components. The $5 \alpha$-dihydrotestosterone content of the hyperplastic canine prostate is reported to be 1.60 $\mu \mathrm{g} / 100 \mathrm{~g}$ tissue (7). Our data demonstrate that only $0.275 \mu \mathrm{g} 5 \alpha$-dihydrotestosterone per $100 \mathrm{~g}$ of hyperplastic prostate maximally may be bound to prostatic androgen receptors and thus suggest that $>80 \%$ of the $5 \alpha$-dihydrotestosterone content of hyperplastic canine prostates is not retained in association with prostatic androgen receptors. We conclude that canine prostate hyperplasia is not a consequence of increased accumulation of $5 \alpha$-dihydrotestosterone due to proliferation of prostatic androgen receptors.

The current data demonstrate the absence of an aging-associated decrease in canine prostate androgen receptor content per cell. This observation is in complete opposition to that for rat prostate androgen receptors. We have demonstrated that ventral prostate cytoplasmic androgen receptor content in SpragueDawley and AXC rats, respectively, is diminished $50-65 \%$ at $2 \mathrm{yr}$ of age and $85 \%$ at $3 \mathrm{yr}$ of age $(19,20)$. Cytoplasmic androgen receptor was not demonstrable in dorsolateral prostate of either breed of rat (19). Ventral and dorsolateral prostate nuclear androgen receptors evidenced a 35-50\% aging-associated decrease in both breeds of rats (19). Additionally, we have identified spontaneous adenocarcinomas of the AXC rat ventral prostate, whereas this lesion was not found in the rat dorsolateral prostate $(22,25)$. The incidence of this adenocarcinoma was $70 \%$ in AXC rats $>30$ mo of age (25). It is interesting to speculate that the high incidence of prostatic hyperplasia and low incidence of adenocarcinoma of the prostate of the aging canine as compared to the absence of hyperplasia and high incidence of adenocarcinoma of the ventral prostate of the aging AXC rat is in some manner related to altered hormonal regulation of cell function which is reflected in the different relationship between aging and prostatic androgen receptor content in these two species.

\section{ACKNOWLEDGMENTS}

The authors are deeply grateful to Dr. Jean-Pierre Raynaud (Roussel-Uclaf) for the generous gifts of radiolabeled and radioinert R1881, and to Dr. Albert Segaloff (Alton Ochsner Foundation) for providing $7 \alpha$-methyl- $\Delta^{14}-19$-nortestosterone. We thank Dr. Bruce McCullough (Southwest Foundation) for histologic characterization of the tissue, and acknowledge the expert technical assistance of Robert W. Klipper and Robert F. Azar.

This investigation has been supported by the National Cancer Institute NO1-CP-33379, National Institute on Aging AG 00090, U. S. Public Health Service Biomedical Research Support Funds, and Research Support Funds from the Southwest Foundation for Research and Education.

\section{REFERENCES}

1. Moore, R. A. 1944. Benign hypertrophy and carcinoma of the prostate. Occurrence and experimental production in animals. Surgery (St. Louis). 16: 152-167.

2. Huggins, C. 1945. The physiology of the prostate gland. Physiol. Rev. 25: 281-295.

3. Berg, O. A. 1958. Parenchymatous hypertrophy of the canine prostate gland. Acta Endocrinol. 27: 140-154.

4. Huggins, C., and P. J. Clark. 1940. Quantitative studies of prostatic secretion. II. The effect of castration and of estrogen injection on the normal and on the hyperplastic prostate glands of dogs.J. Exp. Med. 72: 747-762 + plates.

5. Huggins, C. 1947. The prostatic secretion. Harvey Lect. 42: $148-193$.

6. Ofner, P. 1968. Effects and metabolism of hormones in normal and neoplastic prostate tissue. Vitam. Horm. 26: $237-291$.

7. Gloyna, R. E., P. K. Siiteri, and J. D. Wilson. 1970. Dihydrotestosterone in prostatic hypertrophy. II. The formation and content of dihydrotestosterone in the hypertrophic canine prostate and the effect of dihydrotestosterone on prostate growth in the dog. J. Clin. Invest. 49: $1746-1753$.

8. Jacobi, G. H., and J. D. Wilson. 1976. The formation of $5 \alpha$-androstane- $3 \alpha, 17 \beta$-diol by dog prostate. Endocrinology. 99: 602-610.

9. Walsh, P. C., and J. D. Wilson. 1976. The induction of prostatic hypertrophy in the dog with androstanediol. $J$. Clin. Invest. 57: 1093-1097.

10. Boesel, R. W., R. W. Klipper, and S. A. Shain. 1977. Identification of limited capacity androgen binding components in nuclear and cytoplasmic fractions of canine prostate. Endocr. Res. Commun. 4: 71-84.

11. Huggins, C. 1947. The etiology of benign prostatic hypertrophy. Bull. N. Y. Acad. Med. 23: 696-704.

12. Huggins, C., and R. A. Stevens. 1940. The effect of castration on benign hypertrophy of the prostate in man.J. Urol. 43: 705-714

13. Geller, J., R. Bora, T. Roberts, H. Newman, A. Lin, and R. Silva. 1965. Treatment of benign prostatic hypertrophy with hydroxyprogesterone caproate. Effect on clinical symptoms, morphology, and endocrine function. J. Am. Med. Assoc. 193: 121-128.

14. Wendel, E. F., G. E. Brannen, P. B. Putong, and J. T. Grayhack. 1972. The effect of orchiectomy and estrogens on benign prostatic hyperplasia. J. Urol. 108: 116-119. 
15. Siiteri, P. K., and J. D. Wilson. 1970. Dihydrotestosterone in prostatic hypertrophy. I. The formation and content of dihydrotestosterone in the hypertrophic prostate of man.J. Clin. Invest. 49: 1737-1745.

16. King, R. J. B., and W. I. P. Mainwaring. 1974. In Steroid-Cell Interactions. University Park Press, Baltimore. 41-101.

17. Gorski, J., and F. Gannon. 1976. Current models of steroid hormone action: a critique. Annu. Rev. Physiol. 38: 425-450.

18. Buller, R. E., and B. W. O'Malley. 1976. The biology and mechanism of steroid hormone receptor interaction with the eukaryotic nucleus. Biochem. Pharmacol. 25: 1-12.

19: Shain, S. A., and R. W. Boesel. 1977. Aging-associated diminished rat prostate androgen receptor content concurrent with decreased androgen dependence. Mech. Ageing Dev. 6: 219-232.

20. Shain, S. A., R. W. Boesel, and L. R. Axelrod. 1975. Aging in the rat prostate. Reduction in detectable ventral prostate androgen receptor content. Arch. Biochem Biophys. 167: 247-263.

21. Chamness, G. C., and W. L. McGuire. 1975. Scatchard plots: common errors in correction and interpretation. Steroids. 26: 538-542.

22. Shain, S. A., B. McCullough, and A. Segaloff. 1975. Spontaneous adenocarcinomas of the ventral prostate of aged AXC rats. J. Natl. Cancer Inst. 55: 177-180.

23. Bonne, C., and J-P. Raynaud. 1976. Assay of androgen binding sites by exchange with methyltrienolone ( $R$ 1881). Steroids. 27: 497-507.

24. Scatchard, G. 1949. The attractions of proteins for small molecules and ions. Ann. N. Y. Acad. Sci. 51: 660-672.

25. Shain, S. A., B. McCullough, W. M. Nitchuk, and R. W. Boesel. 1977. Prostate carcinogenesis in the AXC rat. Oncology (Basel). 34: 114-122. 